\title{
Experimental factorial design on hydroesterification of waste cooking oil by subcritical conditions for biodiesel production
}

\author{
Letícia Karen dos Santos a, Rafael Rodrigues Hatanaka ${ }^{a}$, José Eduardo de Oliveira ${ }^{a}$, \\ Danilo Luiz Flumignan ${ }^{\mathrm{a}, \mathrm{b}, *}$ \\ ${ }^{a}$ UNESP - São Paulo State University, Institute of Chemistry, Organic Chemistry Department - Center for Monitoring and Research of the Quality of Fuels, \\ Biofuels, Crude Oil and Derivatives - CEMPEQC, Rua Prof. Francisco Degni, 55, Quitandinha, 14800-900, Araraquara, SP, Brazil \\ ${ }^{\mathrm{b}}$ São Paulo Federal Institute of Education, Science and Technology - IFSP - Campus Matão, Rua Estéfano D'avassi, 625, Nova Cidade, 15, 991-502, Matão, \\ São Paulo, Brazil
}

\section{A R T I C L E I N F O}

\section{Article history:}

Received 18 November 2016

Received in revised form

22 May 2017

Accepted 10 July 2017

Available online 17 July 2017

\section{Keywords:}

Hydroesterification

Waste cooking oil

Free fatty acids

Optimization

Response surface analyses

Biodiesel

\begin{abstract}
A B S T R A C T
Hydroesterification is innovation biodiesel production using low cost feedstock by two-step: hydrolysis of waste cooking oil to FFAs in subcritical water and chemical esterification of FFAs into FAME (biodiesel) with methanol. The purpose was to apply the experimental factorial design to evaluate the influence of reaction variables on the effectiveness of hydrolysis and determine the relationship of FFAs and FAMEs yields. Experiments were conducted in a batch reactor under diverse reaction conditions to determine the optimal parameters for hydrolysis. This analyses indicated that high FFAs yields (95 wt\%) are achieved using $250{ }^{\circ} \mathrm{C}$; $120 \mathrm{~min}$; 100:1 water-to-oil molar ratio and $700 \mathrm{rpm}$. Research results revealed a conversion the FFAs in 98.5 wt\% of FAMEs with high quality by esterification in biodiesel production. This study shows that the biodiesel produced by subcritical/chemical hydroesterification process has similar qualities to the biodiesel obtained by traditional alkaline transesterification, which suggests a promising alternative for biodiesel production.
\end{abstract}

๑) 2017 Elsevier Ltd. All rights reserved.

\section{Introduction}

Recent global climatic modification has been caused largely by the increase of anthropogenic emissions and other gases in the atmosphere. These issues are becoming increasingly relevant the search for renewable energy sources has been intensified [1]. Biodiesel has recently become an attractive alternative to traditional diesel feedstocks due to its physical and chemical characteristics and is currently produced via the transesterification of triglycerides (animal fat and refined vegetable oils) with alkaline catalyst and methanol $[2,3]$.

The major drawback in this process is the acquisition of feedstock due to its sensitivity to free fatty acids (FFAs) and water content, where a small amount of FFAs and water results in soap formation, consumes the catalyst and drastically reduces ester conversion [4-6]. These properties provide a high cost production

* Corresponding author. São Paulo Federal Institute of Education, Science and Technology - IFSP - Campus Matão, Rua Estéfano D'avassi, 625, Nova Cidade, 15991-502, Matão, São Paulo, Brazil. Tel.: +55 1635060700.

E-mail address: dlflumig@yahoo.com.br (D.L. Flumignan). and invalidate use of non-traditional feedstocks, such as waste cooking oils (WCO), crude oils and non-edible plant oil [7].

The feedstocks contributes mostly to the cost of biodiesel, which is reported to be up to $80 \%$ of the biodiesel [8]. One way to reduce the cost of biodiesel is to use low cost feedstocks. Around 15 million tons of WCO are discarded annually worldwide [9]. Its disposal is currently a problem for the environment, which poses the need of intense efforts to perform the reuse and to state its value $[10,11]$. Frying is one the most popular methods of food preparation in modern times [12]. Some common physical changes observed in fat or oil after this processing: (i) an increase in FFAs; (ii) a change in oil colour to dark brown or red; (iii) an increase in viscosity and specific heat; and (iv) a change in surface tension [11,13-16].

The hydroesterification process is the modern alternative for biodiesel production as it allows the use of any feedstock material, regardless of FFA and moisture content; this process involves two steps a hydrolysis followed by esterification $[17,18]$.

The first step is hydrolysis, a chemical reaction between the triglyceride fat or vegetable oil (mono-, di-, and triglycerides) with water, which produces FFAs and glycerol $[19,20]$, intermediate materials with high aggregate value and a wide variety of uses [21].

The non-catalytic hydrolysis reactions are conducted in 
subcritical water conditions, since, at ambient conditions, oil and water are poorly soluble due to their different polarities. With the increase temperature exceeding $250{ }^{\circ} \mathrm{C}$, the relative dielectric constant of water reduces from 80 to 25 , approaching the dielectric characteristics of the non-polar substances such as oils and fats [22-25].

At subcritical state $\left(200-250^{\circ} \mathrm{C}\right)$ the water ionization constant is about 10 , which is three orders of magnitude greater than the ionization constant in environmental conditions [20]. The increase of the ionization constant is directly proportional to the increase in concentration of hydrogen ions, thereby raising the speed of the hydrolysis reaction. The use of water in the sub- or supercritical conditions has demonstrated the ability to achieve the same results as a process that employs the use of catalysis in both acidic and enzymatic conditions [20].

In the second step, the FFAs generated by the hydrolysis are esterified with methanol or ethanol in the presence of an acid catalyst such as the protonated carboxylic acid, which facilitates the nucleophilic attack of the alcohol to carbonyl occurring loss of a water molecule, resulting in a methyl ester (FAME) molecule [26-28]. The advantage is that there is no contamination of biodiesel with glycerol [29] (a co-product of hydrolysis), which is more soluble in water than in methanol. This avoids contamination problems in biodiesel with free or total glycerol (mono-, di- and triglycerides), resulting in a high purity biodiesel.

Here we present the application of the experimental factorial design to evaluate the influence of process parameters (temperature, reaction time, water-to-oil molar ratio and stirrer) on the effectiveness of hydrolysis measured in terms of FFA yields. Other aims were to determine the relationship between FFAs (in hydrolysis) and FAMEs (in esterification) productions. Thus, we propose an innovative strategy in the biodiesel production chain that targets the sustainable use of low quality feedstock and contributes to the increase of the biodiesel in the energy matrix and in the economic, social and environmental developments of this market.

\section{Experimental}

\subsection{Feedstock}

Waste cooking oil (WCO) was obtained from a collection point at the São Paulo Federal Institute of Education, Science and Technology - IFSP (Matão - SP, Brazil), stored in plastic containers at room temperature.

\subsection{Oil analysis}

We carried out the oil analyses in triplicate according to the standard methods published by ASTM (American Society for Testing and Materials), AOCS (American Oil Chemist's Society), Brazilian Technical Standards Association (ABNT) and ET ISO (Federal Democratic Republic of Ethiopia). The performed analyses were free fatty acids (FFAs) and acid number (AOCS Ca 5a-40), water content (ASTM D6304), monoglycerides (MG), diglycerides (DG) and triglycerides (TG) contents (ABNT NBR 15908) and compositional profile (ET ISO 5508).

\subsection{FFAs and acid number by acid-base titration}

An official method proposed by the American Oil Chemist Society (Ca 5a-40) was used to determine the percentage of FFAs in the collected samples. This method can be applied to all crude and refined vegetable oils. The procedure may be described briefly as follows: $3-5 \mathrm{~g}$ of the sample was weighed and charged into a conical flask and 75-100 mL ethyl alcohol (97\%) was added to give a definite and sharp titration end point. Phenolphthalein indicator was then added. The mixture was titrated against sodium hydroxide $\left(1.0 \mathrm{~mol} \mathrm{~L}^{-1}\right)$ until a permanent pink colour persisted for at least $30 \mathrm{~s}$. For waste cooking oil, the weight percentage of FFA was calculated on an oleic acid basis using Eqn. (1) and the acid number basis in Eqn. (2). The samples were titrated in triplicate with a variance of $<0.5 \%$, which is shown as follows.

FFAs $(\%$ oleic acid $)=\frac{V(m L) \cdot C\left(\mathrm{~mol}^{-L^{-1}}\right) \cdot 28.2}{w t \text { of sample }(\mathrm{g})}$

Acid number $(\mathrm{mg} \mathrm{NaOH} / \mathrm{g})=1.99 \times \mathrm{FFA}$

\subsection{Water content by coulometric Karl Fischer titration}

An official method proposed by the American Society for Testing and Materials (ASTM D6304) was used to determine the percentage weight of water in the WCO. This method covers the direct determination of water in crude and refined vegetable oils, petroleum products, lubricants and additives in the range of concentration of $0.001-2.5 \mathrm{wt} \%$. The procedure may be briefly described as follows: an aliquot is injected into the titration vessel of a coulometric Karl Fischer apparatus in which iodine for the Karl Fisher reaction is generated coulometrically at the anode. When all the water has been titrated, excess iodine is detected by an electrometric end point detector and the titration is terminated. Based on the stoichiometry of the reaction, $1 \mathrm{~mol}$ of iodine reacts with $1 \mathrm{~mol}$ of water; thus, the quantity of water is proportional to the total integrated current according to Faraday's Law. The water content was calculated by Eqn. (3).

Water $(w t \%)=\frac{w t . \text { of water titrated }}{(1000 \times w t . \text { of sample })}$

\subsection{Compositional profile and MG, DG and TG contents by GC-FID}

An official method proposed by the Federal Democratic Republic of Ethiopia (ET ISO 5508) and Brazilian Technical Standards Association (ABNT NBR 15908) were used to determine the compositional profile and glycerides contents (wt\%) in the feedstock, respectively. Both determinations were made GC-FID.

In the compositional profile, the chromatographic system for separation and identification of FFAs (wt\%) was configured by crossbond polyethyleneglycol capillary column (Stabilwax, $30 \mathrm{~m} \times 0.25 \mathrm{~mm} \times 25 \mu \mathrm{m}$ ). The initial temperature was $60^{\circ} \mathrm{C}$ for $2 \mathrm{~min}$, increased to $220^{\circ} \mathrm{C}$ at $10^{\circ} \mathrm{C} \mathrm{min}-1$, and finally, to $240{ }^{\circ} \mathrm{C}$ at $5{ }^{\circ} \mathrm{C} \mathrm{min}^{-1}$ and held for $7 \mathrm{~min}$. The injector and detector temperature were at $350{ }^{\circ} \mathrm{C}$ and the sample $(0.5 \mu \mathrm{L})$ was prepared using iso-octane.

In glycerides contents, the chromatographic system for separation and identification of MG, DG and TG (wt\%) was configured by crossbond 5\% Phenyl 95\% dimethylarylene siloxane capillary column (ZB-5HT, $30 \mathrm{~m} \times 0.32 \mathrm{~mm} \times 0.1 \mu \mathrm{m}$ ). The initial temperature was $50{ }^{\circ} \mathrm{C}$ for $1 \mathrm{~min}$, increased to $180^{\circ} \mathrm{C}$ at $15^{\circ} \mathrm{C} \mathrm{min}^{-1}, 230^{\circ} \mathrm{C}$ at $7{ }^{\circ} \mathrm{C}$ min $^{-1}$, and finally, to $380{ }^{\circ} \mathrm{C}$ at $20{ }^{\circ} \mathrm{C} \mathrm{min}^{-1}$ and held for $10 \mathrm{~min}$. The injector and detector temperature was at $380^{\circ} \mathrm{C}$ and the sample $(0.5 \mu \mathrm{L})$ was prepared using heptane.

\subsection{Hydrolysis reaction}

Hydrolysis reactions of WCO feedstock with water in subcritical conditions were carried out in a $300 \mathrm{~mL}$ reactor (AlphaTec, Model $\mathrm{RH}-830)$ at high pressure. After the reaction, the mixture was 
cooled to room temperature and transferred to a separatory funnel. The aqueous phase (lower layer) consisting of water and glycerol was separated by decantation and FFAs phase (upper layer) was analysed in accordance to Section 2.3.

\subsection{Experimental factorial design in hydrolyses reaction}

A $2^{4}$ full factorial design matrix was defined using the values and coded levels given in Table 1 . These variables were used to investigate the conversion of the triglycerides into FFAs in the hydrolyses stage. The JMP Statistical 12 and Matlab R-2013a with regression2 routine were used to generate the matrices, calculate the coefficients of the model, evaluate the significant variables, perform the statistical data analysis and create charts for interpretation. The variables and limits of experimental domain for the reaction (temperature, reaction time, molar ratio water-to-oil and stirrer) were defined based on literature. The response factor of the factorial design was FFAs.

For statistical calculations, the real values of the independent variables were coded as dimensionless values $\left(\mathrm{X}_{\mathrm{i}}\right)$. Five replicates were at the center point were added (runs 17-21) to determine the experimental error and the data reproducibility [30]. Furthermore, these additional data points allow estimation of potential curvatures. Then, the response surface was determined using the values and the coded levels of Tables 1 and 2 .

For four variables, the full factorial model is show in Eqn. (4), where $\mathrm{Y}$ is the predictive response, $\mathrm{X}_{\mathrm{i}}$ are the input variables and $\beta_{\mathrm{i}}$ are constant. The $\beta_{0}$ is the intercept term, $\beta_{\mathrm{i}}$ are the linear terms, $\beta_{\mathrm{ii}}$ are the squared terms, and $\beta_{\mathrm{ij}}$ and $\beta_{\mathrm{ijk}}$ are the interaction terms, which are added to a main effect or first-order model, resulting in:

$$
\begin{aligned}
Y= & \beta_{0}+\beta_{1} X_{1}+\beta_{2} X_{2}+\beta_{3} X_{3}+\beta_{4} X_{4}+\beta_{12} X_{1} X_{2}+\beta_{13} X_{1} X_{3} \\
& +\beta_{14} X_{1} X_{4}+\beta_{23} X_{2} X_{3}+\beta_{24} X_{2} X_{4}+\beta_{123} X_{1} X_{2} X_{3} \\
& +\beta_{124} X_{1} X_{2} X_{4}+\beta_{134} X_{1} X_{2} X_{4}+\beta_{234} X_{2} X_{3} X_{4} \\
& +\beta_{1234} \beta_{1} \beta_{2} \beta_{3} \beta_{4}+\varepsilon
\end{aligned}
$$

In some situations, the curvature in the response function will not be adequately modelled by Eqn. (4). In such cases, a logical model to consider is where the $\beta_{\mathrm{jj}}$ represent pure second-order or quadratic effects, shown in Eqn. (5).

$Y=\beta_{0}+\sum_{j=1}^{K} \beta_{j} X_{j}+\beta_{j}+\sum \sum_{i<j} \beta_{i j} X_{i} X_{j}+\sum_{j=1}^{k} \beta_{j j} X_{j}^{2}+\varepsilon$

The adequacy of the model was tested by analysis of variance (ANOVA) at a 5\% level of significance using Fischer F-test and the Student t-test. The coefficient of determination $\left(R^{2}\right)$ and the adjusted coefficient (adj. $R^{2}$ ) were evaluated for the linear and quadratic models.

The $\mathrm{R}^{2}$ value indicates amount variation the response is explained by the fitted model. Nevertheless, the adjusted $\mathrm{R}^{2}$ is more relevant since it accounts for the number of factors in our model.

Table 1

Codification and levels of four independent variables considered for the DOE to investigate the hydrolyses reactions WCO.

\begin{tabular}{lllll}
\hline Variable & Factor & \multicolumn{2}{l}{ Levels } \\
\cline { 3 - 5 } & & -1 & 0 & 1 \\
\hline Molar Ratio & $\mathrm{X}_{1}$ & $50: 1$ & $75: 1$ & $100: 1$ \\
Temperature $\left({ }^{\circ} \mathrm{C}\right)$ & $\mathrm{X}_{2}$ & 200 & 225 & 250 \\
Reaction Time (min.) & $\mathrm{X}_{3}$ & 30 & 75 & 120 \\
Stirrer (rpm) & $\mathrm{X}_{4}$ & 500 & 750 & 1000 \\
\hline
\end{tabular}

Table 2

Full factorial design matrix for four factors in 21 observations/experiments for hy-

\begin{tabular}{|c|c|c|c|c|c|}
\hline \multirow[t]{2}{*}{ Run } & \multicolumn{4}{|c|}{ Factor } & \multirow[t]{2}{*}{ Responses FFAs Content (wt\%) } \\
\hline & $\mathrm{X}_{1}$ & $\mathrm{X}_{2}$ & $\mathrm{X}_{3}$ & $\mathrm{X}_{4}$ & \\
\hline 1 & - & - & - & - & 7.2 \\
\hline 2 & + & - & - & - & 6.9 \\
\hline 3 & - & + & - & - & 47.9 \\
\hline 4 & + & + & - & - & 59.1 \\
\hline 5 & - & - & + & - & 28.7 \\
\hline 6 & + & - & + & - & 33.0 \\
\hline 7 & - & + & + & - & 81.4 \\
\hline 8 & + & + & + & - & 90.7 \\
\hline 8 & - & - & - & + & 5.2 \\
\hline 10 & + & - & - & + & 10.6 \\
\hline 11 & - & + & - & + & 59.2 \\
\hline 12 & + & + & - & + & 79.3 \\
\hline 13 & - & - & + & + & 33.2 \\
\hline 14 & + & - & + & + & 32.8 \\
\hline 15 & - & + & + & + & 89.5 \\
\hline 16 & + & + & + & + & 95.8 \\
\hline $17^{\mathrm{a}}$ & 0 & 0 & 0 & 0 & 49.5 \\
\hline $18^{\mathrm{a}}$ & 0 & 0 & 0 & 0 & 49.4 \\
\hline $19^{\mathrm{a}}$ & 0 & 0 & 0 & 0 & 49.4 \\
\hline $20^{\mathrm{a}}$ & 0 & 0 & 0 & 0 & 50.5 \\
\hline $21^{\mathrm{a}}$ & 0 & 0 & 0 & 0 & 50.9 \\
\hline
\end{tabular}
drolyses reactions WCO. Variables: $X_{1}-$ Molar Ratio (50:1 to 100:1), $X_{2}-$ Temperature $\left(200-250{ }^{\circ} \mathrm{C}\right), \mathrm{X}_{3}$ - Reaction Time (30-120 min) and $\mathrm{X}_{4}-$ Stirre (500-1000 rpm). ${ }^{\text {a }}$ Five identical experiments the reproducibility set of the center point to provide
an independent estimate of experimental error.

The $\mathrm{R}^{2}$ and the adj. $\mathrm{R}^{2}$ values found are than $99.7 \%$ and more than $99.9 \%$, respectively, for the full model. After the reduction of a number of terms, the prediction equation is simplified; therefore the values of $\mathrm{R}^{2}$ and adj. $\mathrm{R}^{2}$ decrease, found are respectively $95.6 \%$ and $95.8 \%$, which means the correlation between the observed values and the of the contribution of each influential factor.

\subsection{Esterification reaction}

Esterification reaction was performed in three $100 \mathrm{~mL}$ necked flat-bottom flask, equipped with a reflux condensed and hot plate with stirrer. The reaction was carried out using methanol and FFAs derived from the hydrolysis of WCO feedstock. The conditions were conducted out using the optimum values described by Hassan et al. [27]: molar ratio free fatty acids: methanol $1: 3$, concentration of sulfuric acid catalyst $1 \%$ (w/w of FFAs), temperature $65^{\circ} \mathrm{C}$, time $1 \mathrm{~h}$. At the end reaction, the mixture was transferred to a separatory funnel, cooled to room temperature and dried at $80^{\circ} \mathrm{C}$ with nitrogen flow for $30 \mathrm{~min}$.

\subsection{Biodiesel analysis for quality control}

The biodiesel analyses for quality control were carried out according to the standard methods published by ASTM (American Society for Testing and Materials) and ABNT (Brazilian Technical Standards Association) and established by Resolution ANP No. 45 (National Agency of Petroleum, Natural Gas and Biofuels - [31]). The analyses done were specific mass at $20{ }^{\circ} \mathrm{C}$, acid number, kinematic viscosity at $40{ }^{\circ} \mathrm{C}$, water content, ester content, free glycerol, total glycerol, monoglycerides, diglycerides, triglycerides and methanol.

The results were compared with the values established by Resolution ANP No. 45 [31], which establishes the quality control specifications of biodiesel market in Brazil. The Brazilian standards are similar to their European and US counterparts, although they have some added flexibility to take into account the characteristics 
of Brazilian feedstocks.

\section{Results and discussion}

The objective of this investigation is to explore the use of WCO with particular focus on biodiesel production by hydroesterification. At first, we discuss the quality feedstock material and the effects of the variables in the hydrolysis reaction for FFAs production, and secondly, the biodiesel production by esterification and its analysis for quality control.

\subsection{Feedstock analysis characterization}

The FFAs value, acid number and water content in WCO feedstock were $3.37 \pm 0.02$ (wt\%), $6.70 \pm 0.07 \mathrm{mg} \mathrm{NaOH} / \mathrm{g}$ and $2.01 \pm 0.01$ (wt\%), respectively. These values are higher than recommended for biodiesel production by transesterification.

The DG and TG contents in WCO feedstock, determined by GCFID, were $9.88 \pm 0.10$ and $86.14 \pm 0.09$ (wt\%), respectively. The MG content was not detected and quantified. Detailed FFAs compositional profile contains, as weight percentage, mainly, $47.14 \pm 1.35$ as linoleic acid (C18:2), $26.43 \pm 1.97$ as oleic acid (C18:1) and $16.43 \pm 1.44$ as palmitic acid (C16:0). The average molar weight (MWt) was calculated respectively by using Eqn. (6):

$\overline{M W t}=\left(\sum \frac{\boldsymbol{x i}}{M W t i}\right)^{-1}$

where $x i$ is the weight of the fraction of each fatty acid present and MWti is the molecular weight of each constituent. The average molecular weight for WCO was $851.14 \mathrm{~g} \mathrm{~mol}^{-1}$. The chromatography compositional profile was considered to calculate the molar ratio of oil to water in the mixture that was fed into the reactor in hydrolyses process.

\subsection{Influence of process parameters hydrolysis}

Hydrolysis in subcritical conditions is a pseudo-homogeneous first order reversible reaction with the excess of one reactant, usually water in oily phase. This reaction has been shown by Ref. [32] and occur as three stepwise reactions (Eqns. (7)-(9)).

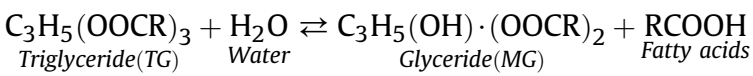

$$
\underset{\text { Diglyceride }(D G)}{\left.\mathrm{C}_{3} \mathrm{H}_{5}(\mathrm{OH}) \cdot \mathrm{OOCR}\right)_{2}}+\underset{\text { Water }}{\mathrm{H}_{2} \mathrm{O}} \underset{\text { Monoglyceride }(M G)}{\stackrel{\mathrm{C}_{3} \mathrm{H}_{5}(\mathrm{OH})_{2}}{(\mathrm{OOCR})_{1}}}+\underset{\text { Fatty acids }}{\mathrm{RCOOH}}
$$

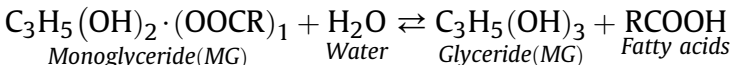

In the first step, the triglycerides (TG) are hydrolyzed into diglycerides (DG); in the second step, diglycerides (DG) are hydrolyzed into monoglycerides (MG), and in the third step, monoglycerides (MG) into glycerol (G) (Eqns. (7)-(9)). FFAs are produced in every step. The total quantity of FFAs is equivalent to the effectiveness of hydrolysis [33].

\subsection{Effect of temperature, molar ratio, time and stirrer on FFAs yield on hydrolyses}

The effect of temperature on the yield of FFAs was investigated between $200^{\circ} \mathrm{C}$ and $250^{\circ} \mathrm{C}$, water-to-oil molar ratio 50 and 100 and reaction time of $120 \mathrm{~min}$. The specific reaction parameters are chosen in order to minimize the reversibility of the reaction. Fig. 1 shows FFAs yields were higher at $250{ }^{\circ} \mathrm{C}$ regardless of the molar ratio water-to-oil, which demonstrates the importance of temperature for the reaction rate hydrolysis.

As can be seen in Fig. 1, the increase in temperature has a positive impact on the hydrolysis. Table 2 shows the experiments with variable $\mathrm{X}_{2}$ in high level provide higher yield of FFAs. As water and oil have weak interactions temperature below $200^{\circ} \mathrm{C}$, the reaction starts at the phase boundary, causing the conversion to be slow [34]. High temperature decreased the dielectric constant of water from 80 to 25 at $250{ }^{\circ} \mathrm{C}$, increasing the interactions of oil in water and the speed of the reaction [35]. Alenezi at al [36]. and Changi et al. [37] observed that the FFAs formed in water in subcritical temperature could act as an acid catalyst in the hydrolysis.

Molar ratio is an essential parameter since that hydrolysis reaction requires the stoichiometric water-to-oil molar ratio 3:1; however, there is a reversible reaction when excess amount of water is used [38]. We did not observe significant increase in the FFA yields with the increase of water-to-oil molar ratio, when observed the same temperature. Still, it is an important effect since
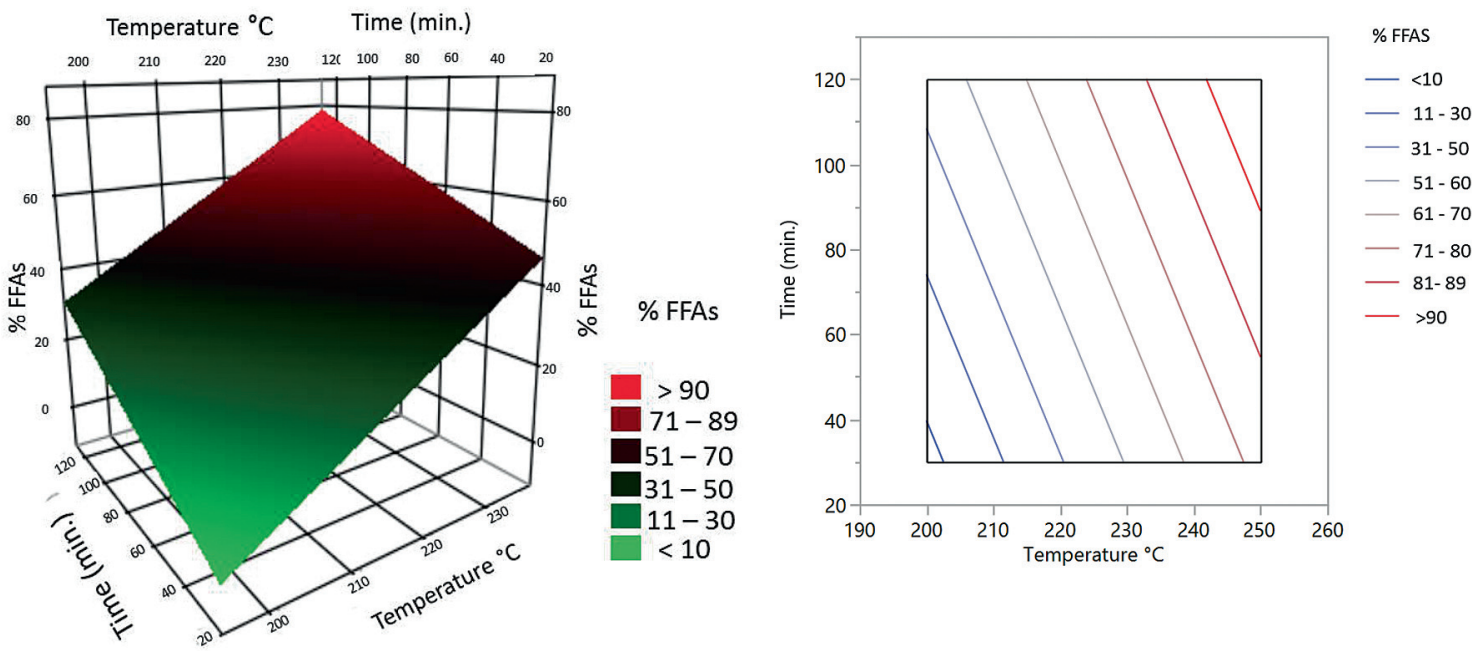

Fig. 1. Response surface and contour plotting and effects of temperature and time, predict model for hydrolysis reaction WCO. 
glycerol, obtained as a co-product, is soluble in water.

The reaction time should be set in a way to provide the highest FFAs yield. Increase in time has a positive effect reaction and such fact was observed by other researchers [36,39-41]. At the start of the hydrolysis reaction, an induction period in which the reaction rate of hydrolysis is very slow. This suggest that FFAs produced in the beginning can act as an acid catalyst in the hydrolysis reaction in subcritical water conversion without the use of any catalyst. Studies of Minami and Saka, report that the fatty acid is dissociated by eliminating a proton, which protons the carbonyl oxygen of the triacylglycerols, diacylglycerols and monoacylglycerols, which favour a nucleophilic attack by water followed by deprotonation of the carboxylic acid. Hence, the conversion rate of FFAs is greater with increasing time. The stirrer did not provide an increase in FFAs yield, however, it is an essential parameter for the water and oil homogenization on the beginning the reaction.

\subsection{Results of regression analysis on hydrolyses}

The optimization of hydrolyses system was conducted using a full factorial design. The variables (molar ratio, temperature, reaction time and stirrer) and results of this study are gathered in Table 2.

The coefficients of the fitted model were calculated and used to quantify the effect of factors on the studied responses. The different factors have more or less impact according to the importance of the coefficient values. Based on the contribution of individual terms to $\mathrm{R}^{2}$ of the model (b values), the greatest contribution on the conversion the glicerides in FFAs found are in temperature $\left(\mathrm{X}_{2}\right)$ and time $\left(\mathrm{X}_{3}\right)$ variables.

Variance test was carried to assess the significance of each variable in the model. P-values lower than 0.05 indicate that a given model variable is considered significant and contributes significantly towards the response. The statistical coefficients at the 95\% confidence level are highlighted in bold in Table 3. According to the p-value, the order of significance of the independent variables for conversion the triglycerides in FFAs is $\mathrm{X}_{2}$ followed by $\mathrm{X}_{3}$. Furthermore, all the variables $\left(\mathrm{X}_{1}\right.$ and $\left.\mathrm{X}_{4}\right)$ and the interaction have not a significant impact on the conversion the triglycerides in FFAs.

A linear regression is typically too simple to reliably fit the response and to consider the use of models for predictions. Therefore, the quality of our model was also evaluated by analysing the curvature term. This term corresponds to the difference between the real value of the response at the middle of the domain obtained from the center points and the coefficient $b_{0}$ given by the regression equation. According to the p-values, there is not a

Table 3

Estimated regression coefficients for regression model.

\begin{tabular}{lll}
\hline & Coefficient & p- value \\
\hline Intercept $\left(\mathrm{b}_{0}\right)$ & 48.104762 & 0.0000 \\
Temperature $\left(\mathrm{X}_{2}\right)$ & $\mathbf{2 7 . 8 3 1 2 5}$ & $<. \mathbf{0 0 0 1}$ \\
Time $\left(\mathrm{X}_{3}\right)$ & $\mathbf{1 3 . 1 0 6 2 5}$ & $<. \mathbf{0 0 0 1}$ \\
Molar Ratio $\left(\mathrm{X}_{1}\right)$ & 3.49375 & 0.0714 \\
Stirrer $\left(\mathrm{X}_{4}\right)$ & 3.16875 & 0.0622 \\
$\mathrm{X}_{2} \mathrm{X}_{3}$ & 0.88125 & 0.1694 \\
$\mathrm{X}_{1} \mathrm{X}_{2}$ & 2.36875 & 0.0576 \\
$\mathrm{X}_{1} \mathrm{X}_{3}$ & -1.05625 & 0.1124 \\
$\mathrm{X}_{2} \mathrm{X}_{4}$ & 2.41875 & 0.0570 \\
$\mathrm{X}_{3} \mathrm{X}_{4}$ & -0.98125 & 0.1339 \\
$\mathrm{X}_{4} \mathrm{X}_{1}$ & 0.43125 & 0.4677 \\
$\mathrm{X}_{1} \mathrm{X}_{2} \mathrm{X}_{3}$ & -0.90625 & 0.1597 \\
$\mathrm{X}_{2} \mathrm{X}_{3} \mathrm{X}_{4}$ & -1.30625 & 0.0632 \\
$\mathrm{X}_{1} \mathrm{X}_{2} \mathrm{X}_{4}$ & 0.30625 & 0.6010 \\
$\mathrm{X}_{1} \mathrm{X}_{3} \mathrm{X}_{4}$ & -1.39375 & 0.0520 \\
$\mathrm{X}_{1} \mathrm{X}_{2} \mathrm{X}_{3} \mathrm{X}_{4}$ & -0.09375 & 0.8711 \\
\hline
\end{tabular}

Table 4

Analysis of variance (ANOVA) for the linear model that represents the hydrolysis for conversion FFAs (wt\%) the WCO.

\begin{tabular}{llllll}
\hline Source of variation & Sum quadratic & Df & Mean quadratic & $\mathrm{F}_{\text {test }}$ & \\
\cline { 4 - 6 } & & & & $\mathrm{F}_{\text {model }}$ & $F_{\text {value }}{ }^{*}$ \\
\hline Regression & 15141.64 & 2 & 7570.81 & 198.86 & 3.55 \\
Residual & 685.27 & 18 & 38.07 & & \\
Total & 15826.91 & 20 & 791.34 & & \\
Pure error & 651.17 & 16 & 40.70 & 0.41 & \\
Lack of fit & 34.10 & 2 & 17.05 & & \\
$\mathrm{R}^{2}$ & 0.96 & $\mathbf{a d j .} \mathbf{R}^{2}$ & 0.98 & & \\
\hline
\end{tabular}

${ }^{*} \mathrm{~F}_{\text {model }}$ values are significant at the $95 \%$ confidence level.

significant curvature. We further refined the model using only the significant variables.

An analysis of variance (ANOVA) for the regression revealed that the model is statistically significant for the studied responses ( $p$ values $<0.05$ ). The strength of the influence of a factor is indicated by the magnitude of the F-value (factors with F-values over 3.55 have a significant influence at the $5 \%$ significance level).

According to ANOVA (Table 4), the F-value of the model regression $\left(F_{\text {model }}=198.86\right)$ was much greater than the tabular $\mathrm{F}_{\mathrm{value}}$ with the same number of degrees of freedom of two sources of variance $\left(\mathrm{F}_{0.05}(2.18)=3.55\right)$, indicating that the treatment differences are highly significant, which confirms that the established regression adequately represents the observed data. Analysis of variance for linear model.

The quality of the model was expressed by the coefficient of determinations $\left(R^{2}\right.$ and adjusted $R^{2}$ ). The $R^{2}$ and the adjusted $R^{2}$ values were 0.96 and 0.98 , respectively, which implies that the model obtained adequately correlates to the experimental data and it can explain $96 \%$ of the variability in the response. Moreover, according to the $F_{\text {value }}$ of "lack of fit" $(0.41)$, the model fitted the data and that lack of fit is not significant relative to the pure error. The large adjusted $R^{2}$ value indicates a good relationship between the experimental data and the fitted model. Based on the statistical analysis of the results, an empirical model was constructed to describe the variation in the FFAs concentration as a function of temperature $\left(\mathrm{T}_{\mathrm{H}}\right)$ and time $\left(\mathrm{H}_{\mathrm{H}}\right)$ (Eqn. (10)).

$\% \boldsymbol{F F A s}=48,10+27,83 \boldsymbol{T}_{\boldsymbol{H}}+13,11 \boldsymbol{H}_{\boldsymbol{H}}$

The response surface and contour graphic shown in Fig. 1 is useful to interpret the variation of the response according to significative variables. Results of statistical analysis show that reaction temperature and time have the most important influence on the FFA yields in subcritical hydrolysis, which was expected given the nature of the reactants (water and oil).

According to the results of the optimization study, the following optimal experimental conditions were chosen: temperature $\left(250{ }^{\circ} \mathrm{C}\right)$, reaction time $(120 \mathrm{~min})$, molar ratio $(100: 1)$ and stirrer (700 rpm).

\subsection{Analysis model and biodiesel production}

In order to evaluate the model proposed in optimized conditions, we investigated the triacylglycerols conversion in FFAs to evaluate the experimental reproducibility with different samples of WCOs, whose results are shown in Table 5. Through individual pairwise comparisons using means and Student's t-tests, it was possible to evaluate the result statistically. In the comparison circles (Fig. 2), the distance between the circles's centers represent the actual difference the sample 16 of full factorial design, it is possible to observe that the samples are statistically equal.

We used the Student's $t$-Test for this set of results, and the 
Table 5

Yield FFAs of hydrolysis reaction in comparison with different samples WCOs in optimal conditions.

\begin{tabular}{ll}
\hline Sample & FFAs Content $(\mathrm{wt} \%)$ \\
\hline WCO 1 & $95.7 \pm 0.06$ \\
WCO 2 & $95.4 \pm 0.03$ \\
WCO 3 & $95.3 \pm 0.13$ \\
WCO 4 & $95.9 \pm 0.10$ \\
WCO 5 & $95.6 \pm 0.52$ \\
WCO 6 & $95.7 \pm 0.09$ \\
WCO 7 & $95.6 \pm 0.50$ \\
WCO 8 & $95.3 \pm 0.04$ \\
WCO 9 & $95.7 \pm 0.12$ \\
WCO 10 & $95.8 \pm 0.03$ \\
\hline
\end{tabular}

critical value for a $95 \%$ confidence level with $4^{\circ}$ of freedom is 2.78 . The values obtained for all samples were less than 2.78 , so there was no significant difference between the results of the hydrolysis reactions using different samples OGR confidence level of 95\%. This result confirms the good fit of the proposed model for the WCO hydrolysis reaction, consistent and reproductive for this array.

In biodiesel production, the product of hydrolysis with high FFAs content was subjected to methyl esterification in order to produce FAMEs (biodiesel). After the esterification reaction $(1 \mathrm{~h})$, the product showed $98.5 \%$ conversion in FAMEs (biodiesel).

\subsection{Biodiesel quality control and technical-economic analyses}

To evaluate the quality control characteristics of biodiesel obtained by hydroesterification route, the FAMEs was analysed according to methods established in Resolution ANP $\mathrm{N}^{\circ} 45$. Table 6 shows the biodiesel properties and the respective limits specifications published by ANP. It can be seen that the biodiesel produced by subcritical/chemical hydroesterification process has similar qualities to the biodiesel obtained by the traditional alkaline transesterification.

In technical-economic analyses, the biggest value in the biodiesel commercialization is the high cost of production which could be contributed by the feedstock price (50\% in the final cost of production) [42-44] has done economic studies projecting a hydroesterification plant in comparison with transesterification route for a period of 10 years. The hydroesterification has a high initial investment, the values will depend on the technology implemented and the installed capacity. However, operating and feedstock costs were less. Moreover the process do not necessity feedstock pre-treatment and steps to neutralize biodiesel and glycerine. According to [45]; the cost of hydroesterification biodiesel plant is around US\$35/ton., while transesterification costs are US\$ 70/ton. In a production with 100,000 ton./year, its represent a saving of US\$ 3.5 million/year. Therefore, this allows the return of capital in a short period of time.

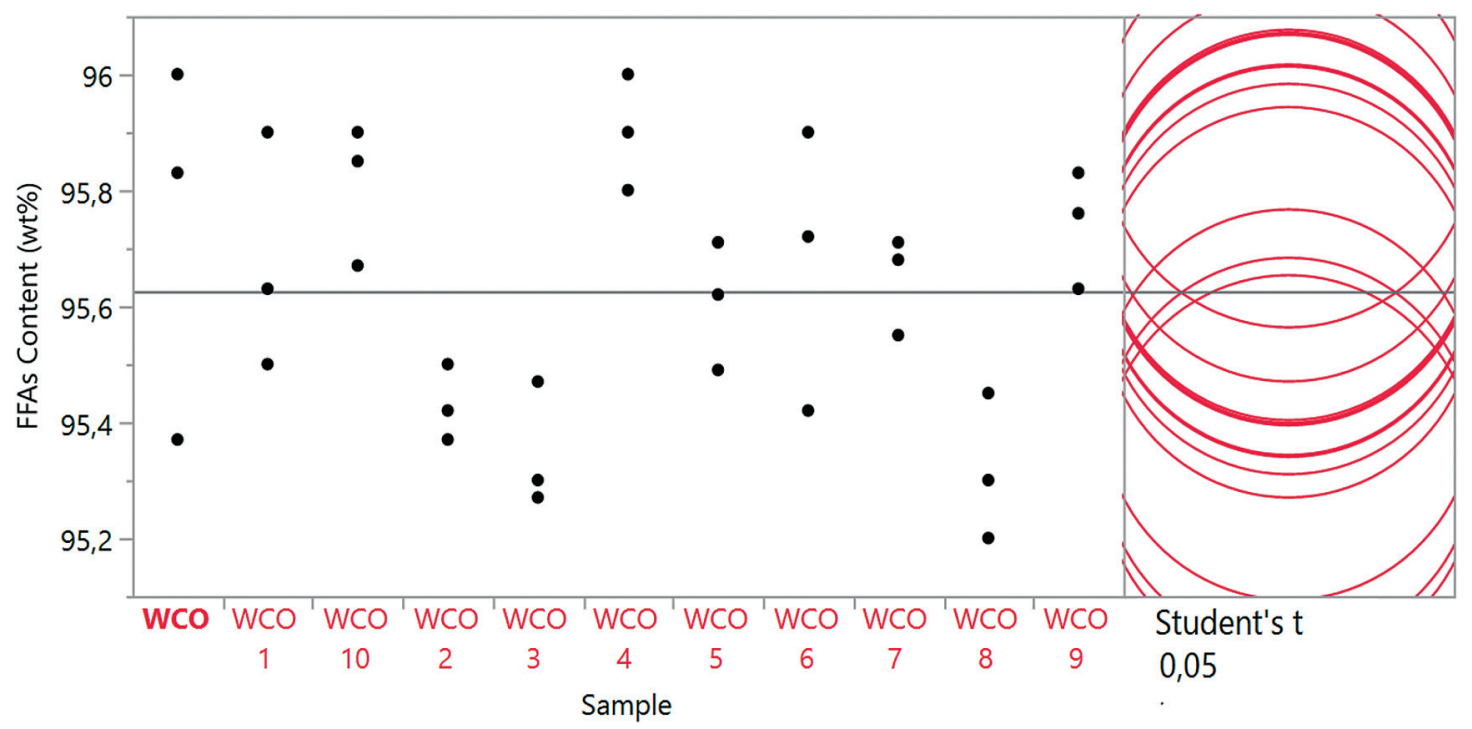

Fig. 2. Analysis model in optimized conditions using Student's t Comparison Circles and means for different samples of WCOs.

Table 6

Analysis of biodiesel production by subcritical/chemical hydroesterification used WCO.

\begin{tabular}{|c|c|c|c|c|}
\hline Property & Units & Limit & Method & Value \\
\hline Specific Mass at $20^{\circ} \mathrm{C}$ & $\mathrm{Kg}\left(\mathrm{m}^{3}\right)^{-1}$ & 850 to 900 & ASTM D4052 & $874.20 \pm 0.01$ \\
\hline Kinematic Viscosity at $40^{\circ} \mathrm{C}$ & $\mathrm{mm}^{2} \mathrm{~s}^{-1}$ & 3.0 to 6.0 & ASTM D445 & $5.7 \pm 0.0$ \\
\hline Water Content, max. & $\mathrm{mg} \mathrm{Kg}^{-1}$ & 200 & ASTM D6305 & $199.56 \pm 0.34$ \\
\hline Ester Content, min. & wt\% & 96.5 & NBR 15764 & $98.5 \pm 0.5$ \\
\hline Monoglycerides, max. & wt\% & 0.7 & NBR 15908 & $0.35 \pm 0.03$ \\
\hline Diglycerides, max. & wt\% & 0.2 & NBR 15908 & $0.13 \pm 0.01$ \\
\hline Triglycerides, max. & $\mathrm{wt} \%$ & 0.2 & NBR 15908 & $0.05 \pm 0.01$ \\
\hline Free glycerol, max. & wt\% & 0.02 & NBR 15908 & $0.01 \pm 0.01$ \\
\hline Total glycerol, max. & wt\% & 0.25 & NBR 15908 & $0.17 \pm 0.03$ \\
\hline Acid Number, max. & $\mathrm{mg} \mathrm{KOH} / \mathrm{g}$ & 0.5 & ASTM D664 & $0.07 \pm 0.01$ \\
\hline Methanol, máx. & wt\% & 0.2 & EN 14110 & $0.0 \pm 0.00$ \\
\hline
\end{tabular}




\section{Conclusions}

The biodiesel production by hydrolysis of WCO in subcritical water was effective at temperature $\left(250{ }^{\circ} \mathrm{C}\right)$, reaction time (120 min), water-to-oil molar ratio (100:1) and stirring (700 rpm), whose analyses indicate high FFAs yields (95 wt\%). The glycerol provided in hydrolyses, as co-product, is free from contamination, therefore, with high value aggregate and with a wide variety of uses. Esterification process provides biodiesel production a yield FAME methyl of $98.5 \mathrm{wt} \%$. The water products can be reapplied in hydrolyses stage. The biodiesel characteristics were satisfactory within quality control specifications established by Resolution ANP No. 45, therefore, biodiesel can be commercialized as fuel or burned for energy co-generation. The subcritical/chemical hydroesterification process also suggest promising alternative to the traditional process of biodiesel production by alkaline transesterification.

\section{Acknowledgements}

This research used resources from Center for Monitoring and Research of the Quality of Fuels, Biofuels, Crude Oil and Derivatives, which is supported by FUNDUNESP, and from MEC/SETEC/CNPq No. 94/2013 (Process: 487939/2013-1).

\section{References}

[1] A. Demirbas, Progress and recent trends in biodiesel fuels, Energy Convers. Manag. 50 (1) (2009) 14-34.

[2] L.C. Meher, D.V. Sagar, S.N. Naik, Technical aspects of biodiesel production by transesterification - a review, Renew. Sustain. Energy Rev. 10 (3) (2006) $248-268$.

[3] G. Vicente, M. Martinez, J. Aracil, Integrated biodiesel production: a comparison of different homogeneous catalysts systems, Bioresour. Technol. 92 (3) (2004) 297-305.

[4] K. Jacobson, R. Gopinath, L.C. Meher, A.K. Dalai, Solid acid catalyzed biodiesel production from waste cooking oil, Appl. Catal. B-Environ. 85 (1-2) (2008) $86-91$.

[5] D.Y.C. Leung, X. Wu, M.K.H. Leung, A review on biodiesel production using catalyzed transesterification, Appl. Energy 87 (4) (2010) 1083-1095.

[6] U. Schuchardt, R. Sercheli, R.M. Vargas, Transesterification of vegetable oils: a review, J. Braz. Chem. Soc. 9 (3) (1998) 199-210.

[7] F. Su, Y.H. Guo, Advancements in solid acid catalysts for biodiesel production, Green Chem. 16 (6) (2014) 2934-2957.

[8] Y.C. Sharma, B. Singh, S.N. Upadhyay, Advancements in development and characterization of biodiesel: a review, Fuel 87 (12) (2008) 2355-2373.

[9] A.F. Lee, J.A. Bennett, J.C. Manayil, K. Wilson, Heterogeneous catalysis for sustainable biodiesel production via esterification and transesterification, Chem. Soc. Rev. 43 (22) (2014) 7887-7916.

[10] R.M. Alberici, V. de Souza, G.F. de Sa, S.R. Morelli, M.N. Eberlin, R.J. Daroda, Used frying oil: a proper feedstock for biodiesel production? Bioenergy Res. 5 (4) (2012) 1002-1008

[11] M.G. Kulkarni, A.K. Dalai, Waste cooking oil-an economical source for biodiesel: a review, Ind. Eng. Chem. Res. 45 (9) (2006) 2901-2913.

[12] A.M. Gamuri, P. Bouchon, Analysis of wheat gluten and starch matrices during deep-fat frying, Food Chem. 115 (3) (2009) 999-1005.

[13] M. Bril'kov, A.B. Falck-Ytter, K.O. Straetkvern, Evaluation of methods for reducing the ash content of waste frying oil processed to biofuel oil, Fuel Process. Technol. 134 (2015) 487-493.

[14] E. Choe, D.B. Min, Chemistry of deep-fat frying oils, J. Food Sci. 72 (5) (2007) R77-R86.

[15] J. Cvengros, Z. Cvengrosova, Used frying oils and fats and their utilization in the production of methyl esters of higher fatty acids, Biomass \& Bioenergy 27 (2) (2004) 173-181.

[16] Q. Zhang, A.S.M. Saleh, J. Chen, Q. Shen, Chemical alterations taken place during deep-fat frying based on certain reaction products: a review, Chem. Phys. Lipids 165 (6) (2012) 662-681.

[17] J.S. de Sousa, E.D. Cavalcanti-Oliveira, D.A.G. Aranda, D.M.G. Freire, Application of lipase from the physic nut (Jatropha curcas L.) to a new hybrid (enzyme/ chemical) hydroesterification process for biodiesel production, J. Mol. Catal. BEnzymatic 65 (1-4) (2010) 133-137.

[18] E. Minami, S. Saka, Kinetics of hydrolysis and methyl esterification for biodiesel production in two-step supercritical methanol process, Fuel 85 (17-18)
(2006) 2479-2483.

[19] E.C.G. Aguieiras, E.D. Cavalcanti-Oliveira, A.M. de Castro, M.A.P. Langone, D.M.G. Freire, Biodiesel production from Acrocomia aculeata acid oil by (enzyme/enzyme) hydroesterification process: use of vegetable lipase and fermented solid as low-cost biocatalysts, Fuel 135 (2014) 315-321.

[20] R. Alenezi, M. Baig, J. Wang, R. Santos, G.A. Leeke, Continuous flow hydrolysis of sunflower oil for biodiesel, Energy Sources, Part A Recovery, Util. Environ. Eff. 32 (5) (2010) 460-468.

[21] T.L. Lohr, Z. Li, R.S. Assary, L.A. Curtiss, T.J. Marks, Mono- and tri-ester hydrogenolysis using tandem catalysis. Scope and mechanism, Energy \& Environ. Sci. 9 (2) (2016) 550-564.

[22] G. Akerlof, Dielectric constants of some organic solvent-water mixtures at various temperatures, J. Am. Chem. Soc. 54 (1932) 4125-4139.

[23] A.G. Carr, R. Mammucari, N.R. Foster, A review of subcritical water as a solvent and its utilisation for the processing of hydrophobic organic compounds, Chem. Eng. J. 172 (1) (2011) 1-17.

[24] R.L. Holliday, J.W. King, G.R. List, Hydrolysis of vegetable oils in sub- and supercritical water, Ind. Eng. Chem. Res. 36 (3) (1997) 932-935.

[25] I. Pavlovic, Z. Knez, M. Skerget, Hydrothermal reactions of agricultural and food processing wastes in sub- and supercritical water: a review of fundamentals, mechanisms, and state of research, J. Agric. Food Chem. 61 (34) (2013) 8003-8025.

[26] D.A.G. Aranda, R.T.P. Santos, N.C.O. Tapanes, A.L.D. Ramos, O.A.C. Antunes, Acid-catalyzed homogeneous esterification reaction for biodiesel production from palm fatty acids, Catal. Lett. 122 (1-2) (2008) 20-25.

[27] S.Z. Hassan, M. Vinjamur, Parametric effects on kinetics of esterification for biodiesel production: a Taguchi approach, Chem. Eng. Sci. 110 (2014) 94-104.

[28] J.M. Marchetti, A.F. Errazu, Esterification of free fatty acids using sulfuric acid as catalyst in the presence of triglycerides, Biomass \& Bioenergy 32 (9) (2008) 892-895.

[29] A.P.P. Bressani, K.C.A. Garcia, D.B. Hirata, A.A. Mendes, Production of alkyl esters from macaw palm oil by a sequential hydrolysis/esterification process using heterogeneous biocatalysts: optimization by response surface methodology, Bioprocess Biosyst. Eng. 38 (2) (2015) 287-297.

[30] D.C. Montgomery, Design and Analysis of Experiments, John Wiley \& Sons, Hoboken, 2013.

[31] AGÊNCIA NACIONAL DO PETRÓLEO, GÁS NATURAL E BIOCOMBUSTÍVEIS, Resolução ANP nº 45, de 25 de agosto de 2014, Diário Oficial da União, Brasília, DF, 2014.

[32] V. Mills, H.K. McClain, Fat Hydrolysis, Ind. Eng. Chem. 41 (9) (1949) $1982-1985$.

[33] A.L. Milliren, J.C. Wissinger, V. Gottumukala, C.A. Schall, Kinetics of soybean oil hydrolysis in subcritical water, Fuel 108 (2013) 277-281.

[34] J.S.S. Pinto, F.M. Lancas, Hydrolysis of corn oil using subcritical water, J. Braz. Chem. Soc. 17 (1) (2006) 85-89.

[35] R.D. Micic, M.D. Tomic, F.E. Kiss, E.B. Nikolic-Djoric, M.D. Simikic, Optimization of hydrolysis in subcritical water as a pretreatment step for biodiesel production by esterification in supercritical methanol, J. Supercrit. Fluids 103 (2015) 90-100.

[36] R. Alenezi, G.A. Leeke, R.C.D. Santos, A.R. Khan, Hydrolysis kinetics of sunflower oil under subcritical water conditions, Chem. Eng. Res. Des. 87 (6A) (2009) 867-873.

[37] S. Changi, T. Pinnarat, P.E. Savage, Mechanistic modeling of hydrolysis and esterification for biofuel processes, Ind. Eng. Chem. Res. 50 (22) (2011) $12471-12478$.

[38] A. Sturzenegger, H. Sturm, Hydrolysis of fats at high temperatures, Ind. Eng Chem. 43 (2) (1951) 510-515.

[39] J. Kansedo, K.T. Lee, Non-catalytic hydrolysis of sea mango (Cerbera odollam) oil and various non-edible oils to improve their solubility in alcohol for biodiesel production, Chem. Eng. J. 237 (2014) 1-7.

[40] J.W. King, R.L. Holliday, G.R. List, Hydrolysis of soybean oil in a subcritical water flow reactor, Green Chem. 1 (6) (1999) 261-264.

[41] D. Kusdiana, S. Saka, Effects of water on biodiesel fuel production by supercritical methanol treatment, Bioresour. Technol. 91 (3) (2004) 289-295.

[42] E.F. Aransiola, T.V. Ojumu, O.O. Oyekola, T.F. Madzimbamuto, D.I.O. IkhuOmoregbe, A review of current technology for biodiesel production: state of the art, Biomass Bioenergy 61 (2014) 276-297, http://dx.doi.org/10.1016/ j.biombioe.2013.11.014.

[43] A.P.G. Encarnação, Geração de Biodiesel Pelos Processos de Transesterificação e Hidroesterificação, Uma Avaliação Econômica. 2007. 144 p, Dissertação (Mestrado em Tecnologia de Processos Químicos e Bioquímicos), Universidade Federal do Rio de Janeiro, Rio de Janeiro, 2007.

[44] D.A.G. Aranda, C.M. Soares, N.O. Tapanes, Techno-economic and life cycle analysis of biodiesel production: perception of land use, climate change, and sustainability measurements, in: S.S. da Silva, A.K. Chandel (Eds.), Biofuels in Brazil, Springer International Publishing, Switzerland, 2014, pp. 351-365.

[45] L.L. Lima, Produção de biodiesel a partir da hidroesterificação dos óleos de mamona e soja. 2007. 206 f, Dissertação (Mestrado em Tecnologia de Processos Químicos e Bioquímicos), Universidade Federal do Rio de Janeiro, Rio de Janeiro, 2007. 